\title{
Participatory epidemiology as an innovative approach in animal health systems research
}

\author{
P. K. TURKSON \\ Department of Animal Science, School of Agriculture, University of Cape Coast, Cape Coast, Ghana
}

\begin{abstract}
This paper provides information on a recent innovative approach in animal health research termed "participatory epidemiology". It seeks to present participatory epidemiology as a tool for research in Ghana, and presents some case studies of the use of participatory epidemiology in Ghana and elsewhere.
\end{abstract}

Provisional communication. Received 10 Feb 06: revised 16 Jun 08.

\section{Introduction}

A major discipline in conventional veterinary medicine is epidemiology, which is defined as "the study of disease in populations and of factors that determine its occurrence" (Thrusfield, 1995). Epidemiology involves observing populations and making inferences from such observations. According to Thrusfield (1995), the five major objectives of conventional epidemiology are to:

- Determine the origin of a disease whose cause is known.

- Investigate and control a disease whose cause is unknown or is poorly understood.

- Obtain information on the ecology and natural history of a disease.

- Plan and monitor disease control programmes.

Assess the economic effects of a disease, analyzing the economic benefits and costs of alternative control programmes.

Putt et al. (1987) outlined the stages involved in epidemiological investigations as:

- A diagnostic phase, which confirms the presence of the disease.

- A descriptive phase involving a description of the populations at risk and the distributions of the disease, in time and space, within the populations.

- An investigative phase, normally involving implementation of field studies to test hypotheses.

- An experimental phase involving setting up of experiments under controlled conditions to test hypotheses in more details, should the results in the investigative phase seem promising.

- An analytical phase involving analyses of the information from investigations and experiments.

- An intervention phase, which examines appropriate methods for controlling the disease, either on-station (experimental 
conditions) or on-farm (field conditions).

- A decision-making phase using knowledge of the epidemiology of the disease to come up with options for control.

- A monitoring phase, which ensures that the control measures on implementation are properly applied, have the desired effect on reducing the incidence of disease, and any externality likely to affect the success of the control programme is detected quickly and rectified.

Essentially, epidemiology has been a quantitative and precise science, and has tended to use statistics for inferences. For a long time, the use of qualitative approaches such as rapid rural appraisal (RRA) or participatory rural appraisal (PRA), more common in the social sciences, has been frowned on by purists of epidemiology. McCrindle, Stewart \& Kiwanuka (1996) defined RRA as a "systematic but semistructured activity carried out in the field by a multi-disciplinary team and designed to rapidly acquire new information with appropriate imprecision."

One core principle of RRA is the use of participatory approach and the acknowledgement and recording of indigenous practice (Mettrick, 1993). The RRA approach has been modified in animal health research and termed variously as situational analysis (Paskin, 1990), market research (Eicher \& Staatz, 1990), veterinary needs analysis (McCrindle et al., 1994), or epidemiological surveys.

Recently, the term "Participatory Epidemiology" (PE) is gaining currency (Catley, 1999). A treatise on PE has been presented by Catley (1999), and forms the basis for much of this paper.

\section{What is Participatory Epidemiology?}

Epidemiologists have of late adopted, adapted, or modified methods of PRA to improve the understanding of livestock keepers and livestock diseases in resource-poor settings and in areas where conventional approaches are difficult to use. This has resulted in the emergence of PE as a distinct branch of veterinary epidemiology (Catley \& Admassu, 2003).

Participatory epidemiology has been defined as the "use of participatory methods to improve understanding of animal health issues" (Catley \& Mariner, 2002a, 2002b), and is based on the following principles:

1. Attitudes and behaviour, requiring practitioners to be willing to learn from indigenous people and to respect local knowledge and culture.

2. Combined methods and triangulation, where methods such as interviewing, scoring and ranking, and visualization are used and combined with conventional epidemiological procedures and tools.

3. Use of key informants who have knowledge and skills in indigenous practices.

4. Action-oriented, because the aim is to obtain information that can be verified with communities, and will form the basis for agreement on appropriate acceptable actions.

5. Methodological flexibility, adaptation and development because the tools are used according to the needs of a given community or organization, and may combine the benefits of participatory approaches and quantitative methods.

According to Mariner \& Paskin (2000), PE is another tool that offers methodologies of an intelligence-gathering nature to further define the complex process called "common sense".

The tools used in PE are similar to those in PRA and include secondary sources, direct observation, interview techniques, visualization techniques, and methods of ranking and scoring (Catley \& Mariner, 2001).

Secondary sources refer to use and review of existing published or grey literature, reports, maps, and databases on the communities and issues of interest.

Direct observations involve having an environmental scan by observing the 
environment and daily activities of livestock owners or keepers.

Interview techniques used are mainly the semistructured type in which a checklist of issues to be covered is used as a point of reference, instead of a questionnaire; and participants are allowed, through open-ended questions, to bring up other topics and issues.

The common visualization techniques in PE are maps, Venn diagram, timeline, and seasonal calendar construction. Maps are used to provide relative positions of resources such as grazing areas, cultivation areas, water sources, woodlands, wildlife, habitats of insect vectors of diseases, trade routes, and seasonal movements. Venn diagrams have been used to illustrate institutional relationships between different players in a particular community, and have been useful in analyzing the relative roles and responsibilities of different organizations in providing services and the links between them. Timeline and seasonal calendars provide powerful tools to describe temporal patterns of a disease in a location, thereby helping in understanding the epidemiology of infectious diseases.

Ranking and scoring are used in prioritising information or providing semi-quantitative estimates of the relative size or impact of categories from the perspective of participants. Table 1 shows examples of PE methods.

\section{Advantages of Participatory Epidemiology}

In spite of reservations about the use of participatory methods in epidemiological studies by purists, some advantages identified by Mariner \& Paskin (2000) include the following:

1. Participatory appraisal may be the only way to collect data from certain marginalized

TABLE 1

Examples of Participatory Epidemiology Methods

\begin{tabular}{|c|c|}
\hline Information required & PE methods \\
\hline \multicolumn{2}{|l|}{ Background information } \\
\hline System boundary & Natural resource maps, social maps \\
\hline Social organization & Social mapping, Venn diagrams \\
\hline Wealth groups & Wealth ranking \\
\hline Relative livestock ownership & Proportional piling \\
\hline Role of livestock in household economy & Livelihood analysis \\
\hline Preferred types of livestock reared & Livestock species scoring \\
\hline Food, income and other benefits from animals & Proportional piling \\
\hline Marketing systems & Flow diagrams, service maps \\
\hline Veterinary services & Service map, Venn diagrams, ranking and scoring \\
\hline Animal husbandry & Seasonal calendars, mobility maps, transects \\
\hline Resources available to rear livestock & Natural resource maps, transects \\
\hline \multicolumn{2}{|l|}{ Epidemiological information } \\
\hline Priority livestock diseases & Disease scoring \\
\hline $\begin{array}{l}\text { Local characterization of diseases according to disease signs and } \\
\text { causes }\end{array}$ & Matrix scoring \\
\hline Estimates of incidence and mortality & Proportional piling; progeny testing \\
\hline History of livestock diseases & Timelines \\
\hline \multicolumn{2}{|l|}{ Seasonal variations in livestock disease, vectors, and } \\
\hline livestock-wildlife interactions & Seasonal calendars \\
\hline Livestock productivity & Progeny testing \\
\hline Contact with neighbouring herds, wildlife, disease vectors & Mapping, mobility maps \\
\hline Areas of disease events & Mapping \\
\hline Preferred control options & Matrix scoring \\
\hline
\end{tabular}

After Catley (1999) and Catley \& Mariner (2001) 
areas such as remote or conflict areas.

2. PA is often cheaper and more flexible than conventional surveys, so that it is usually a more attractive option for poorly resourced veterinary services.

3. The results are often available very rapidly for actions to be taken.

4. It is more flexible and adaptable to new issues arising from the appraisal.

5. It is an effective method used before the more conventional studies for better identification of the scope of a problemthe breadth, depth, and priority issues meriting a more in-depth quantitative study.

6. Participatory appraisal uses what the local people already know as its building blocks, which helps the people to use their own knowledge and skills in disease surveillance and control.

7. Participation empowers the participants, particularly the poor and rural women.

Uses of PA and PE in Animal Health Research According to Catley (1999), participatory appraisal and participatory epidemiology have been used in:

- animal health surveys, needs assessments and action plans;

monitoring and evaluation;

ש. ethnoveterinary data collection;

- participatory disease searching;

- community-based disease control programmes;

- scientific research on viral disease and validation of tick control methods; and

- market research related to veterinary privatization programmes.

Table 2 gives selected examples of where PA and PE have been used in animal health services.

Application of Participatory Appraisal and Participatory Epidemiology in Animal Health Research in Ghana

The use of participatory appraisal or epidemiology in animal health research in Ghana is recent and scant. Table 3 gives some notable examples. Tables 4 and 5 show some findings from the above studies. Table 4 shows the proportions of farmers who mentioned certain signs as indicative of an animal being sick. It showed that farmers were very conversant with the signs and symptoms of diseases. Although they might not know the names of a particular disease, they could be depended on to describe disease syndromes that could be used by veterinarians for differential diagnosis.

Participatory epidemiology was also used for ethno-veterinary studies to find out traditional methods in disease treatment. Table 5 presents some results.

\section{Challenges with Participatory Epidemiology}

The major concern is the qualitative nature of inquiry, which raises questions about reliability and validity. Catley (2000) reported that many veterinarians consider qualitative data to be unreliable, invalid and difficult to incorporate into disease information systems. Other concerns are that the method needs to be carefully explained, so good training of researchers is required (Catley \& Admassu, 2003). Furthermore, for now most of the application has been with pastoral or agropastoral communities in which diagnostic abilities are strong and may be problematic with other types of livestock keepers. In addition, recall is critical to getting credible information. Indigenous livestock keepers, especially pastoralists, may be able to recall disease events over many years and in specific animals, but the ability to do so in other livestock keepers is suspect. Several of these issues are being addressed in the Participatory Approaches to Veterinary Epidemiology (PAVE) Project based in Nairobi, Kenya.

\section{Conclusion}

Participatory epidemiology promises to be a useful tool in addressing issues in animal health and concerns of livestock keepers. It is hoped that with time PE will become acceptable as a tool 
Participatory epidemiology: An innovative approach in animal health research

TABLE 2

Examples of PA and PE Methods Used in Animal Health Services

\begin{tabular}{|c|c|c|}
\hline Country & Description & Reference \\
\hline Ethiopia & Animal health issues featuring in a general needs assessment & $\begin{array}{l}\text { Scoones \& } \\
\text { McCraken (1989) }\end{array}$ \\
\hline Kenya/Zimbabwe & Use of wealth ranking and disease ranking in projects & $\begin{array}{l}\text { Maranga (1992) } \\
\text { Young (1992) }\end{array}$ \\
\hline Afghanistan & $\begin{array}{l}\text { Use of wealth ranking, disease ranking, fodder ranking, and } \\
\text { seasonal calendars during design of an animal health project }\end{array}$ & Leyland (1992) \\
\hline Nigeria & $\begin{array}{l}\text { Use of RRA to study constraints and solutions facing poultry } \\
\text { farmers; comparison of RRA with questionnaire method }\end{array}$ & Sonaiya (1992) \\
\hline Zambia, Ethiopia, Guinea & $\begin{array}{l}\text { Rapid appraisal methodology, including use of livestock disease } \\
\text { calendars and transect walk. }\end{array}$ & Ghirotti (1993) \\
\hline India & $\begin{array}{l}\text { Use of maps, interviews, seasonal calendars, and livelihood } \\
\text { analyses for evaluation of a dairy buffalo project }\end{array}$ & Devavaram (1994) \\
\hline Mozambique & $\begin{array}{l}\text { Use of Venn diagrams for study of institutional linkages } \\
\text { between communities and agencies involved in livestock }\end{array}$ & Braganca (1994) \\
\hline Nepal & $\begin{array}{l}\text { Use of maps, progeny histories, rankings, and interviews } \\
\text { during evaluation of a village animal health worker project }\end{array}$ & Young et al. (1994) \\
\hline Somaliland & $\begin{array}{l}\text { Use of participatory scoring tools, including "before and after" } \\
\text { scoring, for programme review/evaluation }\end{array}$ & $\begin{array}{l}\text { ActionAid } \\
\text { Somaliland (1994) }\end{array}$ \\
\hline South Africa & Use of PA for tick control & $\begin{array}{l}\text { Kiwanuka et al. } \\
\text { (1995) }\end{array}$ \\
\hline Somalia & $\begin{array}{l}\text { Use of PA methods to conduct preliminary investigations on } \\
\text { rinderpest in a remote area }\end{array}$ & $\begin{array}{l}\text { Mariner \& } \\
\text { Flanagan (1996) }\end{array}$ \\
\hline Somaliland & $\begin{array}{l}\text { Use of seasonal calendars and scoring tools to investigate tick } \\
\text { ecology and tick-associated diseases }\end{array}$ & $\begin{array}{l}\text { Catley \& Ahmed } \\
(1996)\end{array}$ \\
\hline South Africa & $\begin{array}{l}\text { RRA methodology within a systems approach to animal health } \\
\text { care needs assessments }\end{array}$ & $\begin{array}{l}\text { McCrindle, Stewart } \\
\text { \& Kiwanaku (1996) }\end{array}$ \\
\hline Ethiopia & $\begin{array}{l}\text { Stakeholder analysis of animal health services based on use } \\
\text { of PA tools, particularly proportional piling }\end{array}$ & $\begin{array}{l}\text { Save the Children UK } \\
\text { (1997) }\end{array}$ \\
\hline South Africa & $\begin{array}{l}\text { Use of rapid appraisal with stakeholders to assess community } \\
\text { veterinary needs }\end{array}$ & McCrindle (1998) \\
\hline Trinidad and Tobago & $\begin{array}{l}\text { Use of school essay method and group interviews as part of } \\
\text { ethnoveterinary study }\end{array}$ & $\begin{array}{l}\text { Lans \& Brown } \\
(1998)\end{array}$ \\
\hline Kenya & $\begin{array}{l}\text { Use of proportional piling to estimate incidence of cattle } \\
\text { diseases }\end{array}$ & Catley et al. (2002) \\
\hline
\end{tabular}

Modified after Catley (1999) 
TABLE 3

Examples of PA in Animal Health Systems Research in Ghana

\begin{tabular}{lc}
\hline Description & Reference \\
\hline Use of PA for information on traditional veterinary knowledge and & Turkson \& Naandam \\
practices in Northern Region of Ghana, specifically East Mamprusi, & $(2002)$ \\
Tamale, and Savelugu-Nanton districts & Turkson (2001, 2004a, \\
Use of PRA to solicit information on privatization of veterinary services in & $2004 \mathrm{~b})$ \\
Ghana, involving livestock owners in Savelugu-Nanton and Tamale & \\
districts, veterinarians and in Veterinary Services Directorate and private & \\
veterinarians &
\end{tabular}

TABLE 4

Proportions of Farmers Mentioning Sign of Disease

\begin{tabular}{|c|c|c|c|}
\hline Sign & $\begin{array}{l}\text { East Mamprusi } \\
(n=1975)(\%)\end{array}$ & $\begin{array}{l}\text { Savelugu-Nanton } \\
(n=273)(\%)\end{array}$ & $\begin{array}{c}\text { Tamale } \\
(n=227)(\%)\end{array}$ \\
\hline Off feed/loss of appetite & 16.3 & 16.5 & 30.0 \\
\hline Rough/starry coat & 7.8 & 15.7 & 10.2 \\
\hline Diarrhoea/soiled hindquarters & 15.0 & 15.4 & 8.5 \\
\hline Dullness/lethargy/weakness & 9.8 & 4.0 & 18.3 \\
\hline Slow walk/abnormal posture & 0.6 & 6.6 & 6.2 \\
\hline Loss of weight/emaciation & 5.9 & 2.6 & 1.3 \\
\hline Running eyes/nose & 11.4 & 5.5 & 2.6 \\
\hline Isolates itself/ stands in one place & 7.9 & 1.5 & 7.0 \\
\hline Coughing & 4.4 & 5.5 & 0.0 \\
\hline Difficulty in breathing & 4.4 & 4.0 & 1.9 \\
\hline Restlessness/frequent crying & 1.1 & 0.7 & 5.8 \\
\hline Animal does not chew cud & 0.0 & 6.2 & 2.6 \\
\hline Loss of hair & 0.7 & 1.5 & 1.3 \\
\hline Recumbency & 3.4 & 1.8 & 2.2 \\
\hline Bloating & 1.8 & 1.1 & 0.0 \\
\hline Groaning/grinding of teeth & 0.4 & 0.4 & 0.0 \\
\hline Lagging behind during grazing & 0.0 & 0.7 & 0.4 \\
\hline Limping & 3.9 & 4.4 & 0.0 \\
\hline Potbelly & 0.0 & 1.5 & 0.0 \\
\hline Faeces not normal & 0.0 & 0.7 & 0.0 \\
\hline Difficulty in/no defaecation & 0.1 & 0.4 & 0.0 \\
\hline Ticks on body & 0.5 & 1.8 & 0.0 \\
\hline Foam/discharge from mouth & 3.4 & 0.7 & 0.4 \\
\hline Swollen body parts & 1.0 & 0.0 & 0.0 \\
\hline Shivering & 0.1 & 0.0 & 0.0 \\
\hline Body feels hot & 0.0 & 0.0 & 1.3 \\
\hline Abnormal discharges from body openings & 0.0 & 0.7 & 0.0 \\
\hline
\end{tabular}

After Turkson \& Naandam (2002) 
TABLE 5

Traditional Methods of Treating Certain Diseases/Conditions in Savelugu-Nanton and Tamale Districts in Northern Ghana

\begin{tabular}{|c|c|}
\hline Problem/disease & Preparation/herb used \\
\hline Anthrax & $\begin{array}{l}\text { Yogu plant } \\
\text { Mahogany bark and roots in water for drinking }\end{array}$ \\
\hline Wounds/sores & $\begin{array}{l}\text { Dried and ground mahogany roots }+ \text { shea butter oil } \\
\text { Mahogany bark and roots in water } \\
\text { Wood ash } \\
\text { Ground and powdered neem leaves applied to wound }\end{array}$ \\
\hline Worms & $\begin{array}{l}\text { Peels of baobab tree soaked in water } \\
\text { Peels of dawadawa tree/roots soaked in water for drinking }\end{array}$ \\
\hline Newcastle disease & Mango/mahogany bark \\
\hline Skin disease & $\begin{array}{l}\text { Shea butter oil } \\
\text { Dirty engine oil } \\
\text { Mahogany bark and roots in water } \\
\text { Dawadawa bark }\end{array}$ \\
\hline Diarrhoea & $\begin{array}{l}\text { Mahogany bark and roots in water } \\
\text { Wood ash }\end{array}$ \\
\hline Ticks & Boiled neem tree leaves for washing \\
\hline Bloated stomach & Saltpetre in water for drenching \\
\hline Snake bite & Palik herb \\
\hline
\end{tabular}

After Turkson \& Naandam (2002)

in veterinary epidemiology and research. From our experiences, PE offers a good platform for animal health systems research in Ghana, because a wealth of information within the livestockkeeping communities is still untapped, but which could be helpful in providing client-based services that meet the real needs, rather than the perceived needs, of livestock keepers.

\section{REFERENCES}

ActionAid Somaliland (1994) Action Aid Somaliland Programme Review/Evaluation.October 1994. Action Aid, London.

Braganca, A. (1994) Livestock rehabilitation programme in Mozambique. RRA Notes 20, 157162.

Catley, A. (1999) Methods on the move: A review of veterinary uses of participatory approaches and methods focusing on experiences in dryland Africa.
International Institute for Environment and Development. 97 pp.

Catley, A. (2000) The use of participatory appraisal by veterinarians in Africa. Office International des Epizooties Scientific and Technical Review 19, 702-714.

Catley, A. \& Admassu, B. (2003) Using participatory epidemiology to assess impact of livestock diseases. FAO-OIE-AU/IBARIAEA Consultative Group Meeting on Contagious Bovine Pleuropneumonia in Africa, 12-14 November 2003. FAO, Rome.

Catley, A. \& Mariner, J. (2002a) Where there is no data: Participatory approaches to veterinary epidemiology in pastoral areas of the Horn of Africa. International Institute for Environment and Development. Issue paper No. 110. 21 pp.

Catley, A. \& Mariner, J. (2002b) Participatory epidemiology and strengthening public sector veterinary services. Sixth EMPRES Expert Consultation. FAO, Rome.

Catley, A. \& Mariner, J. (ed.) (2001) Participatory epidemiology lessons learned and future directions. Proceedings of a Workshop held in Addis Ababa, Ethiopia, November 15-17th 2001.

Catley, A . P. \& Ahmed, A. (1996) Use of participatory rural appraisal (PRA) tools for investigating tick ecology and tick-borne disease in Somaliland. Tropical Animal Health and Production 28,91-98.

Catley, A., Irungu, P., Simuyu, K., Dadye, J., Mwakio, W., Kiragu, J. \& Nyamwaro, S. (2002) Participatory investigation of bovine trypanosomiasis in Tana River District, Kenay. Medical and Veterinary Entomology 16, 1-12. 
Devavaram, J. (1994) Evaluation of a communitybased buffalo project in Tamil Nadu. RRA Notes 20, 133-137.

Eicher, C. K. \& Staatz, J. M. (ed.) (1990) Agricultural development in the Third World, 2nd edn. Johns Hopkins University Press, Baltimore, pp. 41-140, 251-290.

Ghirotti, M. (1993) Rapid appraisal: Benefiting from the experiences and perspectives of livestock breeders. World Animal Review 77, 26-37.

Kiwanuka, A., Stewart, C. G., Bryson, N. R., De Waal, D. T., Tice, G. A., Schoeman, H. S. \& Petty, K. P. (1995) Participatory research and extension approach to tick control in a developing area of South Africa. Proceedings of Second International Congress on Tick-borne pathogens. Kruger National Park, 28 August-1st Sept 1995. 43 pp.

Lans, C. \& Brown, G. (1998) Ethnoveterinary medicines used for ruminants in Trinidad and Tobago. Preventive Veterinary Medicine 35, 149163.

Leyland, T. (1992) Participatory rural appraisal in Afghanistan. In Livestock services for smallholders. Proceedings of an International Seminar held in Yogyakarta, Indonesia, 15-21 November 1992. pp.140-143.

Maranga, S. (1992) Participatory information collection in Kenya and Zimbabwe. In Livestock services for smallholders. Proceedings of an International Seminar held in Yogyakarta, Indonesia, 15-21 November 1992. pp. 37-139.

Mariner, J. C. \& Flanagan, F. (1996) Epidemiological intelligence on the incidence of rinderpest in Somalia and North Eastern Kenya. Food and Agriculture Organization, Rome.

Mariner, J. C. \& Paskin, R. (2000) Manual on participatory epidemiology. FAO Animal Health Manual 10. Food and Agriculture Organization, Rome.

McCrindle, C. M. E. (ed.) (1998) Veterinary needs appraisal: Zuurbekom area, Gauteng. Veterinary Faculty, Medunsa.

McCrindle, C. M. E., Stewart, C. G. \& Kiwanuka, A. (1996) Methodology to assess animal health needs and extent of activities. In Primary animal health activities in Southern Africa. Proceedings of an International Seminar held in Mzuzu, Malawi, February 26-March 8, 1996. DSE/ZEL. pp.136149.

McCrindle, C. M. E., Tice, G., Mogajane, E. M.,
Stewart, C. G. \& Mosupi, H. (1994) An investigation into the potential veterinary needs of a semi-rural, low-income community. Journal of South African Veterinary Association 65, 90-97.

Mettrick, H. (1993) Development orientated research in agriculture-An ICRA textbook. International Centre for Development Orientated Research in Agriculture. Wageningen, The Netherlands. xxi-xxv, 125-172.

Paskin, R. D. (1990) A review of agriculture in Kaokoland with special reference to animal husbandry and veterinary extension. Report to Director of Veterinary Services, Windhoek, Namibia.

Putt, S. N. H., Shaw, A. P. M., Woods, A. J., Tyler, L. \& James, A. D. (1987) Veterinary epidemiology and economics in Africa. ILCA Manual 3. International Livestock Centre for Africa. Addis Ababa.

Save the Children U K (1997) Stakeholder Workshops on Veterinary Service Delivery in the Somali National Regional State (English version), 12-15 August 1997. Save the Children UK Regional Bureau of Agriculture Veterinary Services Support Project. Somali National Regional State. Save the Children UK, Addis Ababa.

Scoones, I. \& McCracken, J. (ed.) (1989) Participatory rapid rural appraisal in Wollo, Ethiopia: Peasant association planning for natural resource management. Ethiopian Red Cross and International Institute for Environment and Development, London.

Sonaiya, E. B. (1992) An integrative approach to the definition of problems and opportunities for smallholder poultry farmers in Nigeria. In Livestock services for smallholders. Proceedings of an International Seminar held in Yogyakarta, Indonesia, 15-21 November 1992. pp.130-132.

Thrusfield, M. (1995) Veterinary epidemiology, 2nd edn. Blackwell Science Ltd, UK.

Turkson, P. K. (2001) Study on privatizing veterinary services delivery system in Ghana. Report of Consultancy commissioned by Ministry of Food and Agriculture (Ghana) and Department for International Development (UK) Policy Steering Facility Committee. 91 pp.

Turkson, P. K. (2004a) Perceptions of livestock owners of private veterinary practice in Ghana. Tropical Animal Health and Production 36, 427434. 
Turkson, P. K. (2004b) Promotion of private veterinary practice in Ghana: Perceptions of veterinarians and veterinary technicians. Tropical Animal Health and Production 36, 413-425.

Turkson, P. K. \& Naandam, J. (2002) Traditional veterinary knowledge and practices in Northern Region of Ghana. Ghana Jnl agric. Sci. 35, 121128 .

Young, J. (1992) Alternative approaches to the identification of smallholder problems and opportunities. In Livestock services for smallholders. Proceedings of an International Seminar held in Yogyakarta, Indonesia, 15-21 November 1992. pp. 123-130.

Young, J., Stoufer, K., Ojha, N. \& Dijkema, H. P. (1994) Animal health training-Nepal's animal health care improvement programme. Intermediate Technology Publications, London. 